\title{
The effects of amiodarone prophylaxis on cardiac dysrhythmia in acute aluminium phosphide poisoning
}

\author{
Mohammad-Reza Beyranvand ${ }^{1}$, Soleyman Farrokhi² ${ }^{2}$ Hassan Peyvandi ${ }^{3}$, Kambiz Soltaninejad ${ }^{4}$, \\ and Shahin Shadnia ${ }^{5}$ \\ ${ }^{1}$ Department of Cardiovascular, Shahid Moddarres Hospital, School of Medicine, Shahid Beheshti University of
Medical Sciences, Tehran, Iran
${ }^{2}$ Department of Internal Medicine, Loghman Hakim Hospital, School of Medicine, Shahid Beheshti University of \\ Medical Sciences, Tehran, Iran \\ ${ }^{3}$ Department of General Surgery, Hearing Disorders Research Center, School of Medicine, Shahid Beheshti University \\ of Medical Sciences, Tehran, Iran \\ ${ }^{4}$ Department of Forensic Toxicology, Legal Medicine Research Center, Legal Medicine Organization, Tehran, Iran \\ ${ }^{5}$ Toxicological Research Center, Center for Excellence in Clinical Toxicology, Department of Clinical Toxicology, \\ Loghman Hakim Hospital, School of Medicine, Shahid Beheshti University of Medical Sciences, Tehran, Iran
}

[Received in June 2018; Similarity Check in July 2018; Accepted in February 2019]

Cardiovascular toxicity is the most common cause of fatality in the first 24 hours of poisoning with aluminium phosphide (AlP). Most often manifesting itself in cardiac dysrhythmias. The aim of this study was to evaluate the benefits of amiodarone prophylaxis against cardiac dysrhythmia in 46 patients with acute AlP poisoning. They were divided in two groups of 23: one receiving amiodarone and the other not (control). The treatment group received amiodarone prophylaxis in the initial intravenous bolus dose of $150 \mathrm{mg}$, followed by a drip of $1 \mathrm{mg} / \mathrm{min}$ for six hours and then of $0.5 \mathrm{mg} / \mathrm{min}$ for eighteen hours. Both groups were Holter-monitored for 24 hours since admission. Save for amiodarone, both groups received the same standard treatment. Amiodarone had a significant beneficial effect in reducing the frequency of STsegment elevation and ventricular fibrillation plus atrial fibrillation ( $\mathrm{P}=0.02$ and $\mathrm{P}=0.01$, respectively), but the groups did not differ significantly in mortality ( 9 vs 11 patients, respectively). The mean time between ICU admission and death (survival time) was significantly longer in the treatment group ( $22 \mathrm{vs} 10 \mathrm{~h}$, respectively; $\mathrm{P}=0.03$ ). Regardless its obvious limitations, our study suggests that even though amiodarone alone did not reduce mortality, it may provide enough time for antioxidant therapy to tip the balance in favour of survival and we therefore advocate its prophylactic use within the first $24 \mathrm{~h}$ of AlP poisoning.

KEY WORDS: AlP; antidysrhythmics; atrial fibrillation; ECG; Holter; rice tablet; ST-segment; toxicity; ventricular fibrilation

Aluminium phosphide (AIP) is used in agriculture due to low cost and high efficacy as a fumigant pesticide. Acute AlP poisoning is mainly reported in Asian countries like India and Iran (1-3) and is the most common cause of death among pesticides, with a mortality rate of $31 \%$ to $77 \%(2-6)$.

Signs and symptoms of acute AlP poisoning include gastrointestinal, cardiovascular, hepatic, renal, and neurologic (1). Most of the deaths occur within the first 24 hours after ingestion due to cardiovascular involvement, dysrhythmias such as ventricular tachycardia (VT), ventricular fibrillation (VF), supra-ventricular tachycardia (SVT), and atrial flutter and fibrillation (AF) in particular (7-10).

Amiodarone is an antidysrhythmic used to treat SVT and ventricular tachydysrhythmia, by blocking repolarisation and prolonging the refractory period of the myocardium,

Corresponding author: Shahin Shadnia MD, PhD, FACMT, Department of Clinical Toxicology, Loghman Hakim Hospital Poison Center, Kamali Street, South Karegar Avenue, Tehran-1333635445, Iran,

E-mail: shahin1380@yahoo.com which prevents tachydysrhythmia. It is associated with improved survival in non-ischaemic cardiomyopathy but not in post-myocardial infarction, yet its use in postmyocardial infarction and congestive heart failure patients is safe $(11,12)$. Amiodarone also improves survival in patients with AF by effectively converting AF to sinus rhythm and maintaining it after conversion (12).

For all these reasons, the aim of this study was to evaluate its potential as prophylaxis against AlP-induced dysrhythmia.

\section{SUBJECTS AND METHODS}

\section{Study population}

This was a prospective, randomised, controlled, open label clinical trial in patients with acute AlP poisoning. The study included 46 patients older than 12 years admitted to the Medical Toxicology Intensive Care Unit (MT ICU) of the Loghman Hakim Hospital Poison Center, Tehran, Iran 
over six months. Patients with the history of diabetes mellitus, cardiovascular, respiratory, renal, and hepatic failure, substance abuse, co-ingestion, advanced medical management for poisoning, and antidysrhythmic therapy started elsewhere before admission were excluded from the study.

The diagnosis was based on the history of exposure, clinical manifestations, and positive silver nitrate test on exhaled breath or stomach content samples. The study was approved by the Ethics Committee of the Shahid Beheshti University of Medical Sciences in Tehran and observed the Declaration of Helsinki.

\section{Treatment protocol}

The treatment started with gastric decontamination in the Emergency Department, followed by immediate admission to the ICU and management based on the same standard protocol for all patients (4-6 g of magnesium sulphate and $4 \mathrm{~g}$ of calcium gluconate by intravenous (IV) infusion daily and adequate hydration), except for amiodarone treatment. IV infusion of $10 \mu \mathrm{g} / \mathrm{min}$ norepinephrine was administered as required. All the patients were treated under the supervision of the same physicians and nurses.

The patients were randomised in two groups: those with even file number were assigned to the treatment group receiving amiodarone prophylaxis $(n=23)$ and those with the odd file number were assigned to control (not receiving amiodarone) $(\mathrm{n}=23)$.
The initial loading dose of $150 \mathrm{mg}$ was given as IV bolus, followed by IV infusions of $1 \mathrm{mg} / \mathrm{min}$ for six hours and then of $0.5 \mathrm{mg} / \mathrm{min}$ for another 18 hours, as described elsewhere (13). Both groups were monitored with a 24-hour Holter from admission to the ICU or until the time of death if it occurred within the first $24 \mathrm{~h}$. Holter records were then given to a cardiologist blind to the treatment and control groups for interpretation. All the patients were followed up until discharge from the hospital or death.

Patient information about sex, age, cause of poisoning, ingested AlP dose, time between ingestion and ICU admission, clinical manifestations and paraclinical findings on admission time, duration of hospitalisation, and outcome were taken from the patients' medical files. All information was kept confidential during the study.

\section{Statistical analysis}

The data were expressed as mean \pm standard deviation (SD), frequency, and ratio and analysed with SPSS version 16 (SPSS Inc., Chicago, IL, USA). Qualitative variables were compared with the chi-square test, and quantitative variables were tested for normality of distribution with the Kolmogorov-Smirnov test. Variables with normal distribution were further tested with Student's $t$-test and others with the Mann-Whitney U-test. P values of 0.05 or less were considered statistically significant.

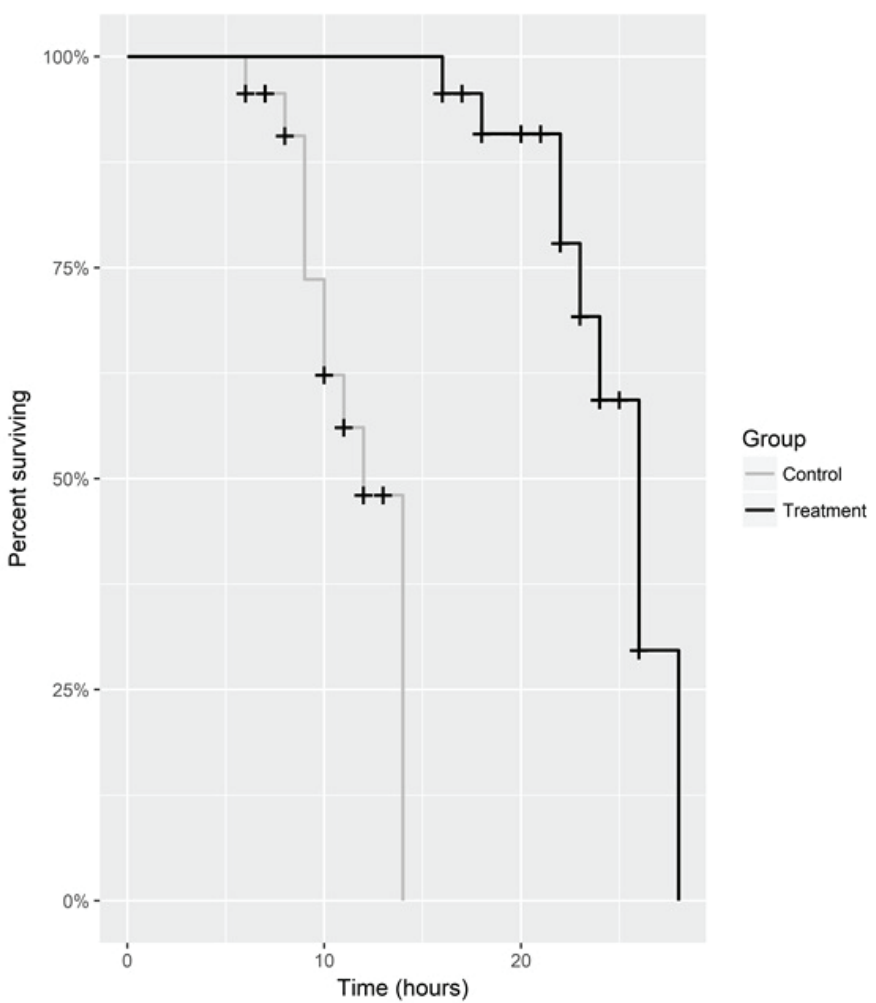

Figure 1 Comparison of survival time between the treatment and control group; +- censored observations (patients discharged from the ICU, with unknown survival time) 
Table 1 Demographic, clinical, and laboratory data of patients with acute AlP poisoning admitted to ICU

\begin{tabular}{|c|c|c|c|c|c|c|}
\hline \multirow{2}{*}{$\begin{array}{l}\text { Parameter } \\
\text { (normal range) }\end{array}$} & & \multicolumn{2}{|c|}{ Treatment group $(n=23)$} & \multicolumn{2}{|c|}{ Control group $(n=23)$} & \multirow{2}{*}{$P$ value } \\
\hline & & $\begin{array}{l}\text { Number } \\
\text { (Ratio) }\end{array}$ & $\begin{array}{l}\text { Mean } \pm \text { SD } \\
\quad \text { (range) }\end{array}$ & $\begin{array}{l}\text { Number } \\
\text { (Ratio) }\end{array}$ & $\begin{array}{l}\text { Mean } \pm \text { SD } \\
\quad \text { (range) }\end{array}$ & \\
\hline \multirow{2}{*}{ Sex } & Women & \multicolumn{2}{|c|}{$14(0.609)$} & \multicolumn{2}{|c|}{$13(0.565)$} & \multirow{2}{*}{0.8} \\
\hline & Men & \multicolumn{2}{|c|}{$9(0.391)$} & \multicolumn{2}{|c|}{$10(0.435)$} & \\
\hline \multicolumn{2}{|l|}{ Age (year) } & \multicolumn{2}{|c|}{$22.7 \pm 6.1(15-36)$} & \multicolumn{2}{|c|}{$25.7 \pm 10.6(13-52)$} & 0.5 \\
\hline \multicolumn{2}{|l|}{ Number of ingested AlP tablets } & $2 \pm 2$ & 25-8) & \multicolumn{2}{|c|}{$1.2 \pm 0.7(0.25-3)$} & 0.08 \\
\hline \multicolumn{2}{|l|}{$\begin{array}{l}\text { Time between AlP ingestion and ICU } \\
\text { admission (hours) }\end{array}$} & \multicolumn{2}{|c|}{$5.6 \pm 5.4(1.2-20)$} & $5.3 \pm 5.8$ & 45-18.1) & 0.2 \\
\hline \multirow{2}{*}{ Abdominal pain } & No & \multicolumn{2}{|c|}{$8(0.348)$} & \multicolumn{2}{|c|}{$7(0.304)$} & \multirow{2}{*}{0.8} \\
\hline & Yes & 15( & 652) & 16( & 696) & \\
\hline \multirow{2}{*}{ Vomiting } & No & & & & & \multirow{2}{*}{0.6} \\
\hline & Yes & 21( & 913) & 20 & 87) & \\
\hline \multirow{2}{*}{ Chest Pain } & No & 12( & 522) & 11( & 478) & \multirow{2}{*}{0.8} \\
\hline & Yes & 11( & 478) & 12( & 522) & \\
\hline \multirow{2}{*}{ Dyspnoea } & No & 15( & 652) & 16( & 696) & \multirow{2}{*}{0.8} \\
\hline & Yes & $8(($ & 78) & $7(0$ & 04) & \\
\hline \multirow{2}{*}{ Loss of consciousness } & No & 22( & 957) & 21( & 914) & \multirow{2}{*}{1} \\
\hline & Yes & & & & & \\
\hline Systolic blood pressure $(120-140 \mathrm{mn}$ & $\mathrm{Hg})$ & $103 \pm 18$. & $(72-150)$ & $94.5 \pm 19$. & $(63-139)$ & 0.3 \\
\hline Diastolic blood pressure $(70-90 \mathrm{mml}$ & & $60.7 \pm 1$ & $40-86)$ & $55.5 \pm 13$ & $(35-88)$ & 0.2 \\
\hline Pulse rate $(60-100 / \mathrm{min})$ & & $108 \pm 17$. & $(70-133)$ & $97.1 \pm 18$ & $(61-135)$ & 0.05 \\
\hline Respiratory rate (12-20/min) & & $15.8 \pm 1$ & $(0-30)$ & $19.3 \pm$ & $0-31)$ & 0.4 \\
\hline Need for intubation and mechanical & No & 19 & 826) & 21 & 913) & \\
\hline ventilation & Yes & $4(($ & 74) & $2(0$ & 87) & 0.1 \\
\hline Blood chemistry & & & & & & \\
\hline $\mathrm{pH}(7.35-7.45)$ & & $7.34 \pm 0.15$ & $5.90-7.35)$ & $7.37 \pm 0.12$ & $.08-7.57)$ & 0.7 \\
\hline $\mathrm{PCO}_{2}(35-45 \mathrm{mmHg})$ & & $35 \pm 14$ & $(19-87)$ & $30.6 \pm 7.2$ & $9.6-45.9)$ & 0.6 \\
\hline Serum $\mathrm{HCO}_{3}(22-26 \mathrm{mEq} / \mathrm{L})$ & & $17.6 \pm 5$ & $(9.4-29)$ & $18.5 \pm 5.9$ & $0.6-32.8)$ & 0.6 \\
\hline $\mathrm{O}_{2}$ saturation $(\%)$ & & $90.3 \pm 5$ & $(77-98)$ & $92.3 \pm 4$ & $(85-98)$ & 0.3 \\
\hline Sodium (135-145 mEq/L) & & $141.5 \pm 4$ & 131-148) & $142.1 \pm 3$ & $136-150)$ & 0.6 \\
\hline Potassium (3.5-5 mEq/L) & & $3.8 \pm 0$ & $(3-5)$ & $3.9 \pm 0.3$ & $.5-4.4)$ & 0.4 \\
\hline Calcium (8.4-10.2 mg/dL) & & $8.9 \pm 0.7$ & $8-10.1)$ & $9.1 \pm 0.8$ & $8-10.5)$ & 0.4 \\
\hline Magnesium (1.9-2.5 mg/dL) & & $2.3 \pm 0$. & $(1.6-3)$ & $2.1 \pm 0.4$ & $.4-2.6)$ & 0.5 \\
\hline Blood glucose $(70-110 \mathrm{mg} / \mathrm{dL})$ & & $103 \pm 18$. & $(72-150)$ & $94.5 \pm 19$ & $(63-139)$ & 0.1 \\
\hline
\end{tabular}

$\mathrm{SD}=$ standard deviation

\section{RESULTS}

In 45 of the 46 cases poisoning was intentional, and 20 patients died (ratio 0.435 ). Table 1 shows the demographic, clinical and laboratory data for both groups on admission to the ICU.

Table 2 compares the frequencies of dysrhythmias registered by the Holter between the groups. Amiodarone significantly lowered the occurrence of ST-segment elevation and $\mathrm{VF}+\mathrm{AF}$.

The need for the administration of vasopressor norepinephrine and mortality did not significantly differ between the treatment and control group [12 vs 13 patients $(\mathrm{P}=1)$ for norepinephrine and $9 \mathrm{vs} 11$ patients for mortality $(\mathrm{P}=0.8)$, respectively].

Median time elapsed between ICU admission and death (survival time) was $23 \mathrm{~h}$ (range: 16-28) in the treatment group and $10 \mathrm{~h}$ (range: 6-14) in the control group $(\mathrm{P}<0.001)$ (Figure 1).

\section{DISCUSSION}

To the best of our knowledge there are only two studies on IV administration of amiodarone in acute AlP poisoning, 
Table 2 The frequencies of dysrhythmias monitored by 24-hour Holter in patients with acute AlP poisoning

\begin{tabular}{lccc}
\hline Type of dysrhythmia & $\begin{array}{c}\text { Treatment group } \\
(\mathbf{n = 2 3 )}\end{array}$ & $\begin{array}{c}\text { Control group } \\
(\mathbf{n = 2 3 )}\end{array}$ & P value \\
\hline Sinus bradycardia & 1 & 1 & 1 \\
\hline First-degree atrioventricular block & 0 & 1 & 0.3 \\
\hline $\begin{array}{l}\text { Second-degree atrioventricular block } \\
\text { (Mobitz type II) }\end{array}$ & 13 & 9 & 0.3 \\
\hline Atrial premature contraction (APC) & 9 & 7 & 0.2 \\
\hline Sinus tachycardia & 3 & 8 & 0.5 \\
\hline Atrial fibrillation (AF) & 2 & 1 & 0.08 \\
\hline Junctional rhythm & 4 & 3 & 0.5 \\
\hline Idioventricular rhythm & 10 & 6 & 0.6 \\
\hline Ventricular premature contraction (VPC) & 9 & 5 & 0.3 \\
\hline Ventricular tachycardia (VT) & 1 & 1 & 0.5 \\
\hline Ventricular fibrillation (VF) & 3 & 3 & 0.3 \\
\hline Left bundle branch block (LBBB) & 7 & 7 & 0.3 \\
\hline Right Bundle Branch Block (RBBB) & 1 & 3 & 0.2 \\
\hline ST-segment elevation & 2 & 11 & $0.02 *$ \\
\hline ST-segment depression & 3 & 13 & 0.6 \\
\hline VF+AF & 8 & 7 & $0.01 *$ \\
\hline VT and VF and AF & 2 & 0.1 \\
\hline Asystole following AF & & 0.06 \\
\hline (R) & 13 & \\
\hline
\end{tabular}

*Statistically significant difference between the two groups $(\mathrm{P}<0.05)$

and one reported no VT response to treatment (14) and the other reported very limited beneficial effects (15). Even though amiodarone prophylaxis in our study significantly decreased the occurrence of $\mathrm{AF}+\mathrm{VF}$ and ST-segment elevation and significantly increased survival time, it did not reduce mortality. However, interpretation of our results is quite limited by the small sample.

Another limitation of our study is that we did not observe or treat myocardial oxidative damage, whereas other studies showed significant beneficial effects of antioxidants against cardiovascular toxicity (16-18). Future studies should therefore combine amiodarone and antioxidant treatment.

Even though amiodarone alone did not reduce mortality, it may provide enough time for antioxidant therapy to tip the balance in favour of survival and we therefore advocate its prophylactic use within the first $24 \mathrm{~h}$ of AlP poisoning.

\section{Acknowledgements}

This article is the part of Dr Soleyman Farrokhi's thesis, who was internal medicine resident at the time of the study. We would also like to thank the Clinical Research Development Center of the Loghman Hakim Hospital for their support.

\section{Conflicts of interest}

None to declare.

\section{REFERENCES}

1. Proudfoot AT. Aluminium and zinc phosphide poisoning. C1in Toxicol 2009;47:89-100. doi: 10.1080/15563650802520675

2. Soltaninejad K, Nelson LS, Bahreini SA, Shadnia S. Fatal aluminum phosphide poisoning in Tehran-Iran from 2007 to 2010. Indian J Med Sci 2012;66:66-70. PMID: 23603623

3. Shadnia S, Sasanian G, Allami P, Hosseini A, Ranjbar A, Amini-Shirazi N, Abdollahi M. A retrospective 7-years study of aluminum phosphide poisoning in Tehran: opportunities for prevention. Hum Exp Toxicol 2009;28:209-13. doi: 10.1177/0960327108097194

4. Soltaninejad K, Faryadi M, Sardari F. Acute pesticide poisoning related deaths in Tehran during the period 20032004. J Forensic Leg Med 2007;14:352-4. doi: 10.1016/j. jflm.2006.12.011

5. Shadnia S, Mehrpour O, Soltaninejad K. A simplified acute physiology score in the prediction of acute aluminum phosphide poisoning outcome. Indian J Med Sci 2010;64:53239. PMID: 21258160

6. Mathai A, Bhanu MS. Acute aluminium phosphide poisoning: Can we predict mortality? Indian J Anaesth 2010;54:302-7. doi: 10.4103/0019-5049.68372

7. Soltaninejad K, Beyranvand MR, Momenzadeh SA, Shadnia S. Electrocardiographic findings and cardiac manifestations in acute aluminum phosphide poisoning. J Forensic Leg Med 2012;19:291-93. doi: 10.1016/j.jflm.2012.02.005

8. Alter P, Grimm W, Maisch B. Lethal heart failure caused by aluminium phosphide poisoning. Intensive Care Med 2001;27:327. PMID: 11280664 
9. Taghaddosinejad F, Farzaneh E, Ghazanfari-Nasrabad M, Eizadi-Mood N, Hajihosseini M, Mehrpour O. The effect of $\mathrm{N}$-acetyl cysteine (NAC) on aluminum phosphide poisoning inducing cardiovascular toxicity: a case-control study. Springerplus 2016;5:1948. doi: 10.1186/s40064-016-3630-2

10. Moghadamnia AA. An update on toxicology of aluminum phosphide. DARU 2012;20:25. doi: 10.1186/2008-2231-2025

11. Naccarelli GV, Wolbrette DL, Patel HM, Luck JC. Amiodarone: clinical trials. Curr Opin Cardiol 2000;15:6472. PMID: 10666663

12. Brendorp B, Pedersen O, Torp-Pedersen C, Sahebzadah N, Køber L. A benefit-risk assessment of class III antiarrhythmic agents. Drug Saf 2002;25:847-65. doi: 10.2165/00002018200225120-00003

13. Susla GM, Suffredini AF, McAreavey D, Solomon MA, Hoffman WD, Nyquist P, Ognibene FP, Shelhamer JH, Masur $\mathrm{H}$, editors. Handbook of Critical Care Drug Therapy. Philadelphia: Lippincott Williams \& Wilkins; 2006.

14. Jadhav AP, Nusair MB, Ingole A, Alpert MA. Unresponsive ventricular tachycardia associated with aluminum phosphide poisoning. Am J Emerg Med 2012;30:633.e3-5. doi: 10.1016/j.ajem.2011.01.026
15. Siwach SB, Singh H, Jagdish, Katyal VK, Bhardwaj G. Cardiac arrhythmias in aluminium phosphide poisoning studied by on continuous holter and cardioscopic monitoring. JAssoc Physicians India 1998;46:598-601. PMID: 12152839

16. Jafari A, Baghaei A, Solgi R, Baeeri M, Chamanara M, Hassani S, Gholami M, Ostad SN, Sharifzadeh M, Abdollahi M. An electrocardiographic, molecular and biochemical approach to explore the cardioprotective effect of vasopressin and milrinone against phosphide toxicity in rats. Food Chem Toxicol 2015;80:182-92. doi: 10.1016/j.fct.2015.02.022

17. Baghaei A, Solgi R, Jafari A, Abdolghaffari AH, Golaghaei A, Asghari MH, Baeeri M, Ostad SN, Sharifzadeh M, Abdollahi M. Molecular and biochemical evidence on the protection of cardiomyocytes from phosphine-induced oxidative stress, mitochondrial dysfunction and apoptosis by acetyl-L-carnitine. Environ Toxicol Pharmacol 2016;42:307. doi: 10.1016/j.etap.2015.12.019

18. Azad A, Lall SB, Mittra S. Effect of N-acetylcysteine and L-NAME on aluminium phosphide induced cardiovascular toxicity in rats. Acta Pharmacol Sin 2001;22:298-304. PMID: 11742581

\section{Djelotvornost amiodarona u profilaksi srčane disritmije uzrokovane akutnim otrovanjem aluminijevim fosfidom}

Najčešći uzrok smrti u prva 24 sata od otrovanja aluminijevim fosfidom (AlP) jesu njegovi toksični učinci na srce i krvožilje. Oni se obično manifestiraju srčanim disritmijama. Cilj je ovoga ispitivanja bio procijeniti blagotvorne učinke amiodarona u profilaksi srčane disritmije u 46 bolesnika primljenih na intenzivnu njegu s otrovanjem AlP-om. Bolesnici su podijeljeni u dvije skupine od 23 ispitanika. Jedna je primala amiodaron, a druga (kontrolna) nije. Ostalo liječenje bilo je standardno i identično u objema skupinama. Amiodaronska se je profilaksa sastojala od udarne intravenske bolusne doze od $150 \mathrm{mg}$, nakon čega je uslijedila infuzija u dozi od $1 \mathrm{mg} / \mathrm{min}$ prvih šest sati, a zatim od 0,5 $\mathrm{mg} / \mathrm{min}$ sljedećih osamnaest sati. Obje su skupine od prijama na intenzivnu njegu bile nadzirane 24-satnim holterom. Amiodaron je iskazao značajnu djelotvornost u smanjenju učestalosti povišenoga ST-segmenta odnosno ventrikulske i atrijske fibrilacije $(\mathrm{P}=0,02$ odnosno $\mathrm{P}=0,01$ ), ali nije značajno smanjio smrtnost ( 9 bolesnika u skupini na amiodaronu odnosno $11 \mathrm{u}$ kontrolnoj skupini). Srednje vrijeme od prijama na intenzivnu njegu do smrti (vrijeme preživljenja), međutim, značajno se produžilo u skupini na amiodaronu ( $22 \mathrm{~h}$ prema $10 \mathrm{~h}$ u kontrolnoj skupini; $\mathrm{P}=0,03$ ). Unatoč jasnim ograničenjima, napose zbog premaloga uzorka, ovo ispitivanje upućuje na to da amiodaron može dovoljno produžiti vrijeme preživljenja i time dati dovoljno vremena antioksidacijskom liječenju da spasi život te iz tog razloga preporučujemo njegovu profilaktičku primjenu u prva 24 sata od otrovanja AlP-om.

KLJUČNE RIJEČI: AlP; antidisritmici; atrijska fibrilacija; EKG; holter; ST-segment; toksičnost; ventrikulska fibrilacija 